\title{
A Segregação Socioeducacional no Distrito Federal do Brasil*
}

\author{
Elaine de Almeida Cabral' (1) \\ Silvia Cristina Yannoulas' (D)
}

\section{RESUMO}

Este artigo discute a relação entre educação, pobreza e desigualdade social por meio da análise da segregação socioeducacional no Distrito Federal do Brasil, considerando a distribuição da renda per capita familiar entre as regiões administrativas, bem como dos alunos beneficiários do Programa Bolsa Família e da infraestrutura física das escolas públicas que atendem esse público, com o objetivo de compreender o processo de pauperização na/da escola. O embasamento teórico se deu na discussão das categorias exclusão, desigualdade e segregação. Foram analisados dados de 2018 e 2019, provenientes do Ministério da Cidadania, do Censo Escolar do Instituto Nacional de Estudos e Pesquisas Educacionais Anísio Teixeira, da Secretaria de Educação do Distrito Federal e da Companhia de Planejamento do Distrito Federal, que permitiram constatar a influência da segregação socioespacial no DF sobre o atendimento aos alunos beneficiários do PBF.

\section{PALAVRAS-CHAVE}

educação; pobreza; desigualdade social; segregação socioeducacional.

'Universidade de Brasília, Brasília, DF, Brasil.

* Resultados parciais de pesquisa do projeto de doutorado em política social na Universidade de Brasília (UnB) e de Produtividade em Pesquisa Chamada CNPq n. 12/2017. Este recebeu Auxílio Pesquisador do Decanato de Pesquisa e Inovação da UnB, edital n. 4/2019. 


\title{
SOCIO-EDUCATIONAL SEGREGATION IN THE FEDERAL DISTRICT OF BRAZIL
}

\begin{abstract}
This article discusses the relationship between education, poverty, and social inequality by means of the analysis of socio-educational segregation in the Federal District of Brazil, considering the distribution of per capita family income between administrative regions, as well as the beneficiaries of Programa Bolsa Família and the physical infrastructure of public schools that serve this audience, in order to understand the impoverishment process in/of the school. The theoretical basis was the discussion of the categories exclusion, inequality, and segregation. Data from 2018 and 2019, from the Ministry of Citizenship, the School Census of Instituto Nacional de Estudos e Pesquisas Educacionais Anísio Teixeira (National Institute of Educational Study and Research "Anísio Teixeira"), the Department of Education of the Federal District, and Companhia de Planejamento do Distrito Federal (Federal District Planning Company) were analyzed, which allowed us to verify the influence of socio-spatial segregation in the DF on the assistance to students benefiting from the PBF.
\end{abstract}

\section{KEYWORDS}

education; poverty; social inequality; socio-educational segregation.

\section{SEGREGACIÓN SOCIOEDUCATIVA EN EL DISTRITO FEDERAL DE BRASIL}

\section{RESUMEN}

Este artículo discute la relación entre educación, pobreza y desigualdad social a partir del análisis de la segregación socioeducativa en el Distrito Federal de Brasil (DF), considerando la distribución del ingreso familiar per capita entre las regiones administrativas, así como los beneficiarios del Programa Bolsa Familia (PBF) y la infraestructura física de las escuelas públicas de este público, con el fin de comprender el proceso de empobrecimiento en/de la escuela. La base teórica se fundamenta en la discusión de las categorías de exclusión, desigualdad y segregación. Se analizaron datos de 2018 y 2019 del Ministerio de la Ciudadanía, del Censo Escolar del Instituto Nacional de Estudios e Investigaciones Educacionales Anísio Teixeira (INEP), de la Secretaría de Educación del Distrito Federal y de la Compañía de Planeamiento del Distrito Federal (Codeplan), que permitieron verificar la influencia de la segregación socioespacial en el DF en laatención a los alumnos de educación básica que se benefician del PBF.

educación; pobreza; desigualdad social; segregación socioeducativa. 


\section{INTRODUÇÃO}

A instituição escolar, seu formato particular na sociedade capitalista contemporânea, é o próprio local dos embates e antagonismos que definem os resultados atingíveis por indivíduos (trajetórias), grupos e populações específicas (circuitos). A escola é multideterminada, e da correlação de forças no seu espaço interior dependerão as trajetórias percorridas e os circuitos habitados cotidianamente pelos estudantes de diferentes classes sociais, raças/etnias e gêneros, suas escolhas no sistema educacional, e, de maneira decorrente, no mundo do trabalho. Essas limitações determinam uma função compensatória para as atuais redes públicas de educação, e sinalizariam uma função paliativa para as profissionais da educação básica, como gestoras da pobreza dos alunos que frequentam a escola pública ${ }^{1}$. Nesse sentido, o debate sobre a universalização da educação básica deveria ser acompanhado de uma reflexão crítica sobre o papel que o sistema educacional assume na realização de políticas sociais focalizadas, tais como a política de assistência social, e, mais especificamente, o Programa Bolsa Família (PBF) (Yannoulas, 2013).

Propomos aqui analisar as expressões materiais da contraditória relação entre políticas sociais e educacionais, no estudo da territorialização dos processos de segregação socioeducacional. O objetivo é relacionar os conhecimentos sobre pobreza e desigualdades sociais às políticas educacionais e assistenciais voltadas para a alteração do quadro de pobreza e pobreza extrema, com a finalidade de traçar um mapeamento da segregação socioeducacional no Distrito Federal (DF) ${ }^{2}$.

Ainda que a educação básica seja um dever do Estado, e, portanto, um direito da população, a implementação de programas de transferência de renda condicionados à frequência escolar sofreu diversificados questionamentos, tanto da área educacional quanto da política social. Assim, queremos provocar o debate sobre os desafios postos pela quase universalização da educação básica no Brasil e no DF (em torno de 98\%), e o papel que os programas de transferência de renda cumpriram na indução desse processo nas últimas duas décadas. Se, por um lado, a inclusão pela via desses programas focalizados visa atender aos ditames da manutenção do sistema capitalista, por outro, não podemos esquecer o caráter de luta social na história do direito à educação.

As políticas sociais focalizadas de caráter compensatório não propiciam uma ação sobre os fatores estruturais determinantes da pobreza; mesmo assim, provocaram uma possibilidade ímpar de reflexão sobre processos de expansão da matrícula na educação básica, permanência e aproveitamento com sucesso dos estudantes pobres na escola, e até mudanças nas práxis escolares, conforme vários estudos corroboram:

1 A expressão "gestão da pobreza" associada à educação básica é de Oliveira (2000). Neste texto, optamos por usar o gênero gramatical feminino para fazer referência às categorias profissionais predominantemente femininas, como: assistente social, pedagoga, professora, psicóloga, entre outras.

2 Segundo Préteceille (2013, p. 442), “A palavra segregação designa, ao mesmo tempo, o ato voluntário de separar e o resultado da separação [...] leva a se definir a segregação urbana como a distribuição desigual dos grupos sociais no espaço da cidade." 
De um lado, esses programas não foram potentes para superar as práticas conservadoras presentes na escola, já que não rompem com a lógica que lhe deu origem e por buscarem, em última instância, a perpetuação do sistema, especialmente quando este é ameaçado pela fragmentação social. Mas, noutro sentido, as mediações realizadas por políticas dessa natureza promovem ações de inclusão de um novo contingente social que visam à garantia de direitos, ainda que de forma pontual, notadamente as que realizam atividades que privilegiam a formação global do aluno e a elevação de sua autoestima. (Vinhaes, 2012, p. 29).

Este estudo encontrou inspiração nas pesquisas sobre baixa frequência nas escolas desenvolvidas pela UnB (Duarte, 2013) e pela UFPR (Schneider et al.,2017); sobre o perfil dos professores, pela UFSC (Silveira, 2017); sobre a influência do território no desempenho escolar, pela UFMG (D’Agostini, 2017); e sobre condições e recursos nas escolas, com ênfase na infraestrutura escolar (Gomes e Duarte, 2017). No caso concreto desta apresentação, procuramos demonstrar quantitativamente (com base em dados oficiais, de acesso público e livre) e territorialmente (por meio de mapas), a inscrição da relação entre educação, pobreza e desigualdade social a partir de duas questões específicas:

- a distribuição desigual de beneficiários/as do Programa Bolsa Família nas escolas das regiões administrativas do DF; e

- a disponibilidade de equipamentos escolares e infraestrutura nas escolas das diferentes regiões administrativas do DF.

Os dados provenientes do Cadastro Único e do acompanhamento escolar do PBF, bem como os dados do Censo Escolar do Instituto Nacional de Estudos e Pesquisas Educacionais Anísio Teixeira (INEP) e da Secretaria de Estado de Educação do Distrito Federal (SEE-DF) foram determinantes para compreender a territorialização dos processos excludentes da escola pública.

Inicialmente, foram cruzados os dados do Ministério da Cidadania sobre os alunos beneficiários do Programa Bolsa Família no DF, no ano de 2019, com as informações do Censo Escolar 2019 do INEP, a fim de identificar as escolas públicas. Em seguida, esses dados foram cruzados com as informações da SEE-DF sobre a região administrativa das escolas, a fim de identificar a distribuição espacial dos estudantes beneficiários do PBF.

Para a análise da infraestrutura escolar no DF, foram utilizados microdados do Censo Escolar 2018, e consideradas as escolas públicas em atividade naquele ano. Foram utilizados dados do formulário de escola referentes à caracterização e infraestrutura. Utilizamos, neste caso, o ano de 2018, por estarem consolidados os dados necessários à data de realização deste estudo.

Para o mapeamento das variáveis analisadas, foi utilizada a ferramenta QGIS $3.12^{3}$, com arquivo vetorial da Companhia de Planejamento do Distrito Federal

3 O QGIS é um Sistema de Informação Geográfica (SIG) de Código Aberto, licenciado segundo a Licença Pública Geral GNU. O QGIS é um projeto oficial da Open Source Geospatial Foundation (OSGeo). A versão utilizada neste estudo é o QGIS 3.12. 
(Codeplan), contendo as 31 regiões administrativas do DF existentes até o início de 2019.

\section{SOBRE AS CATEGORIAS EXCLUSÃO, DESIGUALDADE E SEGREGAÇÃO EDUCACIONAIS}

Em texto anterior, nos debruçamos sobre as categorias analíticas úteis para estudar a relação entre a pobreza e a educação (Yannoulas, 2013). Recuperaremos e atualizaremos aqui algumas questões. Muito em voga na virada do milênio, a categoria exclusão inspirou grandes estudos que marcaram a elaboração de políticas sociais no Brasil. O exemplo mais claro é o Atlas da Exclusão Social no Brasil, publicado pela primeira vez em 2002 com base nos dados do Censo de 2000, e atualizado em 2014 com base no Censo de 2010 (Guerra, Pochmann e Silva, 2014). Para os autores da análise, que classifica a totalidade dos municípios brasileiros, a exclusão social é um processo inerente ao desenvolvimento capitalista, multidimensional e relativo, referindo três dimensões de análise: vida digna, conhecimento e vulnerabilidade juvenil; e incluindo sete indicadores: pobreza, emprego, desigualdade, alfabetização, escolaridade, concentração juvenil e violência. O estudo é proposto pelos organizadores como subsídio para a formulação de políticas que priorizem o território, no intuito de reduzir os aspectos perversos da exclusão social, com vistas à superação das desigualdades. Para os autores, o conceito de exclusão social aponta para o isolamento de certos grupos no interior da sociedade, produto de uma progressão cumulativa de fatores ao longo do tempo, que impedem a participação plena na política, economia, sociedade e cultura, além do acesso ao padrão de vida considerado aceitável. Seria menos limitado que o de pobreza, embora a pobreza seja reconhecida como um dos componentes da condição de exclusão. Exclusão é escolhida como categoria para se opor à visão "alienada, pasteurizada e convencional” dos organismos internacionais, que, à época, defendiam um receituário com medidas orientadas ao enfrentamento da pobreza ${ }^{4}$.

Um conjunto de pensadores utiliza a categoria de exclusão na perspectiva da inclusão excludente ou da exclusão ao interior da escola, como Gentili (2002). Também Silva (2009) opta pela categoria exclusão para realizar uma descrição detalhada da experiência escolar na perspectiva das crianças pobres, e constata as enormes dificuldades que enfrenta a infância pobre para frequentar a escola.

Os alunos muito pobres constituem um desafio para as professoras, que trabalham em inacreditáveis condições de precariedade na maioria das escolas públicas das periferias. Esses estudantes muitas vezes são apenas “tolerados”, e não verdadeiramente incluídos, por falta de opções, sensibilidade ou conhecimento para desenvolver outro tipo de trabalho pedagógico.

Freitas (2002) objetiva entender a lógica das modificações introduzidas na política educacional, e se debruça especificamente sobre a progressão automática

4 Em 2010, o DF ocupou a posição 1.031 entre a totalidade dos municípios brasileiros, com um índice de exclusão calculado em 0,698 (Guerra, Pochmann e Silva, 2014, p. $142,97,102)$. 
como uma forma dissimulada de reduzir custos econômicos, sociais e políticos advindos das formas de exclusão tradicionais objetivas (pela via da repetência e evasão). Há uma "internalização dos custos", no sentido de que o sistema escolar toma consciência do volume de investimento econômico que envolve a problemática do fracasso escolar (custo econômico), e se propõe a desenvolver uma estratégia de "exclusão branda" no interior da própria escola, "internalização da exclusão" (evitando os custos sociais e políticos do fracasso escolar). Essas modificações são introduzidas sem alterar em essência os processos discriminatórios que se desenvolvem na escola a partir de elementos subjetivos, que colocam o próprio excluído como responsável pela exclusão (autoexclusão, exclusão entre ciclos, trilhas de progressão diferenciadas).

Paiva (2012), que estudou escolas com grande participação de estudantes beneficiários do PBF na Região Administrativa do DF denominada Planaltina no período 1995-2004, discute as limitações da categoria exclusão social para apreender os sentidos dos programas de transferência condicionada de renda no sentido de promover transformações no espaço escolar. Com base em autores de cunho marxista e não marxista, Paiva (2012, p. 116) afirma:

[...] o conceito de exclusão social termina por se referir às mais variadas realidades, às vezes de caráter contraditório, outras vezes é utilizado como substitutivo de conceitos históricos, entendidos como ultrapassados na discussão hodierna, tais como os conceitos de pobreza, marginalidade, desigualdade, etc. Interessa observar que o uso do termo exclusão se dá também por modismo [...] o termo exclusão acaba por não definir nada.

A autora entende que a exclusão é característica intrínseca da forma em que opera o sistema capitalista; que assumir o conceito de exclusão seria negar a concepção de classes sociais presente na sociedade capitalista (por sobrepor "excluídos" e "operários"), e, consequentemente, exclusão não seria uma categoria analítica potente. Entretanto, admitindo a imprecisão e inadequação conceituais apontadas, a autora reconhece a importância do conceito para mostrar certas complexidades das práticas escolares, e opta por utilizar "processos excludentes da escola" como movimentos necessários à lógica do capital, caracterizando o que, na literatura, é reconhecido como "escolas despossuídas", nas quais a inclusão é de caráter subordinado, e coloca "a escola como parte de uma lógica social contraditória, capaz de negar-se a si mesma”:

O sistema educacional reproduz na escola os processos excludentes evidenciados na sociedade. Isso explica por que, nesse contexto, pode se identificar desde aqueles a quem foi negado o acesso à escola, como um contingente que adentra ao espaço escolar em condições fragilizadas e que por isso mesmo ou ali não permanecem, ou quando isso ocorre o fazem em condições adversas a sua formação cidadã. Ou seja, encontram-se no processo educativo de forma explicitamente mais desvantajosa que os demais. Desvantagem essa consolidada pela introdução, por meio do poder público, de uma estrutura dual de escola. 
Uma dualidade que não se explicita somente pela presença de uma escola privada e de uma escola estatal, mas, também, pela diferenciação principalmente de ordem estrutural das escolas mantidas pelo Estado. (Paiva, 2012, p. 122-123).

Outro grupo de estudos concentra seus esforços na categoria desigualdade, pois entende que adotar o conceito de exclusão levaria a considerar os problemas dos pobres como "residuais" ou "técnicos", um problema não político ou de direitos, mas de eficiência administrativa, da alçada dos especialistas em problemas sociais. Esse seria o caso da tese de doutorado de Peregrino (2010). A autora procurou mostrar, por meio de estudo de caso no Rio de Janeiro, como a escola não apenas reproduz, mas reinventa perversamente a desigualdade social por meio da fragmentação interna da escola, com práticas de seletividade na distribuição de alunos por turmas (terminais, híbridas e plenas) e turnos (matutino, intermediário ou "da fome" e vespertino): escola dual que classifica e distribui os desiguais por espaços e tempos escolares. Peregrino foca seu olhar nas trajetórias percorridas pelos jovens pobres na escola, fundamentalmente a partir das desigualdades que marcam seus percursos. Para a autora, a instituição escolar atual permite às camadas populares o acesso e a permanência prolongada, e, paralelamente, transforma os diferentes em desiguais, em um processo sutil e de degradação contínua do sistema educacional, utilizando-se, para tanto, do denominado efeito turma.

Sobre esse efeito turma, Alavarse (2009) pormenoriza as estratégias adotadas na escola, que, sob o pretexto de estimular o desenvolvimento dos alunos, nivelando-os pela idade ou pela suposta capacidade, já são gestadas de forma a reproduzir desigualdades:

outro efeito correlato, mais denso politicamente, advém do fato de que as turmas cuja "homogeneidade" é serem constituídas por alunos com menor aproveitamento acabam, contraditoriamente, recebendo menos atenção e esforços de trabalho pedagógico [...] E nessas turmas as diferenças entre os alunos tendem, no mínimo, a se manter, mantendo também a diferença em relação a outras turmas e consolidando um processo de exclusão ou restrição no acesso ao conhecimento que se agrava com o passar do tempo. (Alavarse, 2009, p. 45).

Guimarães-Iosif (2009) utiliza também o conceito de desigualdade, e realiza uma abordagem de estudos de casos múltiplos em escolas da Região Administrativa do DF denominada Paranoá, com alta concentração de beneficiários do PBF. Guimarães-Iosif tem como hipótese o entendimento de que as condições de trabalho docente impedem a existência de uma educação de qualidade, capaz de emancipar os sujeitos. As professoras consideram que a escola deve se preocupar exclusivamente com a aprendizagem, e não com questões relacionadas à situação de pobreza ou à desigualdade social. E ainda salientam que a incorporação de programas de transferência de renda no cotidiano escolar faz com que os alunos e pais não enxerguem na escola um espaço educacional, e sim uma fonte de recursos financeiros.

Em seu artigo, Bottinelli (2017) nos apresenta uma minuciosa genealogia dos conceitos organizadores da produção acadêmica argentina na área da sociologia da 
educação, com destaque especial para o conceito de segmentação desenvolvido por Braslavsky (1985) (entendida como a constituição de circuitos ou redes educacionais diferenciadas horizontalmente, com finalidades específicas para cada grupo social, porém mantendo o sistema como referência totalizadora), de fragmentação na abordagem de Tiramonti (2005) (compartimentos estanques da oferta educacional diferenciada para cada grupo social, com a presença de fraturas múltiplas que questionam o caráter de sistema, incluída aqui a predominância da descentralização e de uma matriz mercadocêntrica própria dos anos 1990), e de segregação segundo Gasparini et al. (2011) e outros autores contemporâneos (demanda educacional específica de cada grupo social, em termos de territórios e instituições, com migração seletiva especialmente da classe média, e intensificação quanto à constituição de espaços escolares homogêneos internamente e altamente diferenciados de outros, e grande influência do eixo público-privado). Esses conceitos foram utilizados sequencialmente na produção acadêmica argentina, para apontar o processo de heterogeneização do sistema educacional e afastamento do modelo único de escola. Foram utilizados e discutidos por numerosos pesquisadores/as, que, por meio de pesquisas, aportaram grande densidade empírica e consequente aprofundamento teórico. Bottinelli (2017) postula que esses conceitos não seriam totalmente diferentes entre si, mas cada um deles concentra-se em diferentes aspectos, identificando causas distintas das desigualdades educacionais, algumas endógenas ao sistema educacional, e outras exógenas, relativas ao modelo de acumulação, às modalidades da intervenção do Estado e às mudanças da estrutura social. Assim, segundo o autor, a atual intensificação da segregação gera a instauração de instituições educacionais públicas marcadas pelo perfil social específico que massivamente as frequenta, localizadas geograficamente em setores urbanos periféricos.

Van Zanten (2011), associada à corrente interpretativa do capital cultural e social forte na França, prefere falar de segregação escolar utilizando termos associados, como periferia, territórios fechados, bairros em dificuldades, efeito-vizinhança, entre outros. Há vários verbetes no dicionário por ela organizado que tratam da segregação escolar e da criação de Zonas de Educação Prioritárias (ZEPs). Por exemplo, Oberti (2011) destaca que os estudos sobre a segregação escolar se interessam pela distribuição dos alunos nos estabelecimentos segundo sua origem social e étnica, procurando saber se a homogeneidade social e étnica dos bairros ou dos estabelecimentos escolares contribuiria para reforçar as desigualdades educacionais. Já para Maloutas (2011), as políticas que tratam mais do bairro (como as ZEPs) do que dos grupos desfavorecidos se fundamentam na hipótese de que a pobreza aumenta quando concentrada em determinado espaço, e que essas políticas seriam capazes de contrabalançar os efeitos negativos de vizinhança. Para Ben-Ayed (2011), a territorialização da ação educativa faz referência também a uma leitura da escola na perspectiva social, pois permite observar as consequências nas experiências escolares (de estudantes e docentes) da inscrição do estabelecimento em um determinado território. Essa perspectiva seria herdeira de paradigmas marxistas, que pensam o espaço social como um espaço de conflitos entre grupos antagônicos. Entretanto, segundo os autores dos três verbetes mencionados, seria necessária uma análise minuciosa dos efeitos perversos de tais políticas de discriminação positiva, porque poderiam favorecer a estigmatização e o aumento das desigualdades: 
A incidência do território sobre os percursos escolares resulta, assim, da combinação de fenômenos complexos que associam fatores externos ao sistema de ensino (variáveis demográficas, taxa de urbanização, segregações urbanas) e fatores internos (modos de regulação das migrações escolares, presença de docentes experientes, cooperação duradora entre profissionais, parcerias institucionais). Essas diferentes fontes de variações locais dos percursos escolares contestam a ilusão de unidade do sistema escolar: elas permitem compreender melhor o que impele as famílias e os profissionais a fugir de certos estabelecimentos e territórios estigmatizados, além de questionarem a capacidade das políticas educativas para equalizar as condições de escolarização entre os estabelecimentos escolares e entre os territórios. (Ben-Ayed, 2011, p. 765).

Para o caso brasileiro, embora as pesquisas com a perspectiva de compreender as conexões entre território e desigualdade escolar sejam relativamente recentes, já permitem nutrir a formulação de políticas educacionais e a transformação de práticas escolares, pois apontam para a existência de vínculos entre desigualdades socioespaciais e segregação escolar. Os estudos desenvolvidos por Alves e Passador (2011), Stoco e Almeida (2011), Duarte (2013), Saraiva (2015) e Ribeiro e Vóvio (2017), por exemplo, apresentam resultados sólidos com base em ferramentas estatísticas sobre a influência da vizinhança e da escola na vida escolar dos alunos em situação de pobreza.

Para Porto-Gonçalves (2006, p. 42), “o território tende a naturalizar as relações sociais e de poder, pois se torna abrigo, lugar onde cada qual se sente em casa, mesmo que numa sociedade dividida". O autor alerta mais à frente, entretanto: "a tensão que hoje vivemos é a melhor expressão que a conformação territorial hegemônica já não consegue mais oferecer abrigo". Nesse sentido, as políticas de caráter territorial não podem desconsiderar a desigualdade e a segregação socioespacial imposta e os mecanismos de exclusão que continuarão a ser reproduzidos.

Inserida na corrente interpretativa da gestão pública de necessidades e serviços em espaços socioterritoriais difíceis, Sposati (2000) coordenou a elaboração do Mapa da Exclusão/Inclusão Social do Município de São Paulo, em parceria com organizações não governamentais. A pesquisa considera o fracasso escolar como indicador de processos excludentes. Sposati classifica o fracasso em Fracasso Premeditado (resultante da omissão da ação das autoridades e políticas públicas) e Fracasso Possível (resultado de condições eventuais e circunstanciais). A primeira condição para o não fracasso é conseguir uma vaga na escola, e o estudo provou que não há planejamento de localização da rede que contemple a realidade da população: há "excesso" de vagas em escolas públicas de bairros nobres, onde as crianças frequentam em maior medida escolas particulares, e falta de vagas em escolas públicas localizadas em bairros cuja renda é menor (o que observamos acontecer no DF de maneira semelhante). Outros fatores agravam essa situação de não acesso ou suspensão das aulas: enchentes, desabamentos, famílias abrigadas nas escolas, reuniões de pais/mães ou professoras. Sposati (2011) destaca que, ultrapassada a barreira do acesso, há falta de incentivos para permanecer na escola, principalmente pela distância entre escola e realidade pessoal e comunitária dos alunos de setores populares, pelas 
péssimas condições dos prédios e equipamentos escolares públicos, e pelos trabalhos (domésticos e/ou remunerados) que os alunos são obrigados a desenvolver fora da escola. A alarmante precarização dos anos 1990 passou a exigir novas respostas das políticas sociais fundamentais, como a de educação e da saúde. Não basta a política de educação assegurar as vagas necessárias para incluir todas as crianças, adolescentes e jovens, é preciso afiançar condições para a presença com qualidade dos alunos: construir o acesso ao transporte escolar, alimentação, material didático, uniforme, desmercadorizando as condições que permitem a frequência e o aproveitamento.

\section{A ORGANIZAÇÃO SOCIOESPACIAL DO DF A PARTIR DA CONSTRUÇÃO DE BRASÍLIA}

Nascida há 60 anos, as justificativas que levam a provocar essa reflexão sobre Brasilia são, em grande medida, histórico-sócio-territoriais. Segundo Peluso (2003), o primeiro momento do planejamento da construção de Brasília está relacionado à crise da cidade capitalista e à impossibilidade de acesso à terra pelas massas proletárias empobrecidas. O plano de construção de uma nova capital para o Brasil refletia o desejo do Estado de apresentar uma cidade que, por um lado, refletisse o desenvolvimento econômico que se almejava para o País, e, por outro lado, estivesse "livre" das mazelas sociais e do caos urbano, baseando-se na perspectiva racionalista oriunda do urbanismo científico europeu. Nesse sentido, "as mazelas dos grandes centros seriam afastadas dessa cidade burocrática, planejada para o Brasil do futuro" (Peluso, 2003, p. 8).

Apesar do plano inicial, já se esperava que, com o crescimento populacional, novas áreas habitacionais viessem a ser criadas, especialmente para abrigar os trabalhadores que participaram das obras de construção da capital e suas famílias. Logo após a inauguração da cidade, as demandas dos trabalhadores vindos de diferentes regiões do País começaram a se apresentar, mas, mesmo com a previsão do crescimento populacional, o Estado não atuou para garantir-lhes os direitos essenciais para permanência na cidade. Conforme Campos (1991, p. 103), nesse momento, “o agente Estado, ao contrário de sua atuação precedente (clientelista e beneficiadora dos interesses dos segmentos de posição social mais privilegiada), exerce um forte papel de controle social e de exacerbação das desigualdades sociais". Em volta do núcleo administrativo de Brasília, foi construída uma rede viária que determinava a periferização dessas novas áreas: "as soluções de planejamento propostas foram conservadoras, dentro do estilo de periferização e regulação da massa trabalhadora. Assim, Brasília rapidamente adquiriu sua forma urbana polinucleada, um centro cercado de cidades-satélites, à medida que a população aumentava"(Peluso, 2003, p. 10).

O rápido crescimento urbano costuma vir acompanhado da desorganização espacial das cidades, e em Brasília não foi diferente. O resultado foi a não absorção desse crescimento nos limites do Plano Piloto e seu enraizamento nas denominadas "cidades satélites" - núcleos dormitórios periféricos que iniciaram o processo de segregação espacial urbana. Os primeiros núcleos foram: Planaltina, situada a $42 \mathrm{~km}$; Brazlândia, a 47 km; Núcleo Bandeirante, a 15 km; Taguatinga, a 25 km; Sobradinho, a 22 km; Gama, a 38 km; Guará, a 13 km; Ceilândia, a 30 km; e Samambaia, a $40 \mathrm{~km}$. O movimento de expansão do centro para as cidades satélites foi acompanhado pela valorização da terra, com as altas dos aluguéis e preços dos terrenos: 
Com exceção do Guará e de Taguatinga, cujos setores têm pouca representação na classe que representa as piores situações de carência sócio-econômica, as cidades satélites apresentam-se com variações significativas entre as melhores e piores situações, revelando níveis acentuados de desigualdade e forte segregação espacial. Nesse último caso encontram-se Santa Maria, Recanto das Emas, Samambaia, Planaltina e principalmente a Vila Estrutural, que situada nas proximidades da Via Estrutural, representa a maior área de invasão de Brasília. Essa ocupação encontra-se em processo de expansão e apresenta certa heterogeneidade quanto às suas características, embora em sua maior parte seja observada a falta de infra-estrutura básica e urbanística, residências precárias e a presença de lixões. (Lopes e Costa, 2005, p. 11).

Atualmente, segundo a Secretaria de Estado de Fazenda, Planejamento, Orçamento e Gestão (SEFP/DF), o DF está dividido em 33 Regiões Administrativas: Brasília, Gama, Taguatinga, Brazlândia, Sobradinho, Planaltina, Paranoá, Núcleo Bandeirante, Ceilândia, Guará, Cruzeiro, Samambaia, Santa Maria, São Sebastião, Recanto das Emas, Lago Sul, Riacho Fundo, Lago Norte, Candangolândia, Águas Claras, Riacho Fundo II, Sudoeste/Octogonal, Varjão, Park Way, Sobradinho II, Setor Complementar de Indústria e Abastecimento, Jardim Botânico, Itapoã, Setor de Indústria e Abastecimento (SIA), Vicente Pires, Fercal, e, a partir de 2019, Pôr do Sol/Sol Nascente e Arniqueiras. Entretanto, para efeitos deste artigo, foram consideradas apenas as primeiras 31 regiões administrativas, sobre as quais foi possível obter dados desagregados 5 .

A desigualdade de renda entre as regiões administrativas do DF pode ser observada na Tabela 1, no qual apresentamos a renda domiciliar per capita e o Índice de Gini para cada uma delas, com base nos dados da Pesquisa Distrital por Amostra de Domicílios - PDAD (Codeplan, 2018) ${ }^{6}$. Observa-se pela tabela que nove regiões administrativas possuem renda domiciliar per capita inferior a um salário mínimo ( $\mathrm{R} \$ 1.045,00$, a partir de $1^{\circ}$ de fevereiro de 2020): Samambaia, Santa Maria, Itapoã, Recanto das Emas, Varjão, Paranoá, Fercal, Riacho Fundo II e Scia-Estrutural. Essas regiões se originaram de ocupações irregulares do solo ou pela remoção de habitantes de diferentes ocupações e seu estabelecimento em uma nova área.

Analisando o Índice de Gini por região administrativa, podemos ter uma melhor noção da desigualdade social interna a cada uma delas. Na região administrativa com maior renda domiciliar per capita, Lago Sul, observa-se um dos menores valores para o índice, o que demonstra maior homogeneidade de renda entre os

5 Não foram consideradas neste estudo as regiões administrativas de Pôr do Sol/Sol Nascente e Arniqueiras, pois, até o início de 2019, a primeira compunha a região de Ceilândia, e a segunda, de Águas Claras.

6 Conforme Wolffenbüttel (2004, p. 80): "o Índice de Gini, criado pelo matemático italiano Conrado Gini, é um instrumento para medir o grau de concentração de renda em determinado grupo. Ele aponta a diferença entre os rendimentos dos mais pobres e dos mais ricos. Numericamente, varia de zero a um (alguns apresentam de zero a cem)". $\mathrm{O}$ valor zero indica que todos têm a mesma renda, enquanto o valor um (ou cem) indica que uma só pessoa detém toda a riqueza. 

Tabela 1 - Renda domiciliar per capita e Índice de Gini por
região administrativa - Distrito Federal, 2018.

\begin{tabular}{|c|c|c|}
\hline Região Administrativa & Renda domiciliar per capita (R\$) & Índice de Gini \\
\hline Lago Sul & $8.317,20$ & 0,39 \\
\hline Sudoeste/Octogonal & $7.074,20$ & 0,43 \\
\hline Plano Piloto & $6.770,20$ & 0,46 \\
\hline Lago Norte & $6.394,00$ & 0,47 \\
\hline Park Way & $5.959,70$ & 0,50 \\
\hline Jardim Botânico & $5.872,10$ & 0,40 \\
\hline Águas Claras & $4.407,50$ & 0,44 \\
\hline $\begin{array}{l}\text { Setor de Indústria e } \\
\text { Abastecimento (SIA) }\end{array}$ & $3.809,40$ & 0,35 \\
\hline Cruzeiro & $3.754,80$ & 0,38 \\
\hline Guará & $3.645,60$ & 0,48 \\
\hline Vicente Pires & $2.691,40$ & 0,53 \\
\hline Núcleo Bandeirante & $2.381,10$ & 0,53 \\
\hline Sobradinho II & $2.362,50$ & 0,50 \\
\hline Taguatinga & $2.206,20$ & 0,49 \\
\hline Sobradinho & $2.127,10$ & 0,49 \\
\hline Gama & $1.597,10$ & 0,50 \\
\hline Candangolândia & $1.415,70$ & 0,57 \\
\hline São Sebastião & $1.359,60$ & 0,46 \\
\hline Riacho Fundo & $1.310,50$ & 0,49 \\
\hline Planaltina & $1.140,60$ & 0,47 \\
\hline Brazlândia & $1.120,60$ & 0,49 \\
\hline Ceilândia & $1.120,00$ & 0,49 \\
\hline Samambaia & 992,40 & 0,56 \\
\hline Santa Maria & 977,00 & 0,50 \\
\hline Itapoã & 930,80 & 0,47 \\
\hline Recanto das Emas & 857,70 & 0,46 \\
\hline Varjão & 834,20 & 0,46 \\
\hline Paranoá & 826,40 & 0,44 \\
\hline Fercal & 815,90 & 0,45 \\
\hline Riacho Fundo II & 797,60 & 0,49 \\
\hline Scia-Estrutural & 570,30 & 0,43 \\
\hline Distrito Federal & $2.461,40$ & 0,58 \\
\hline
\end{tabular}

Fonte: Elaboração própria, com base na Pesquisa Distrital por Amostra de Domicílios 2018 (Companhia de Planejamento do Distrito Federal). 
seus habitantes. Entretanto, Samambaia apresenta um dos maiores valores para o índice - o que demonstra maior distância entre os que têm maior e menor renda - e está entre as regiões com menor renda domiciliar per capita.

Se o DF possui a maior renda per capita do país, $10 \%$ da sua população (sem considerar o Entorno $)^{7}$ consiste de famílias com renda mensal de, no máximo, dois salários mínimos. Assim, em Brasília, convivem uma população visível com altíssima renda e uma população invisibilizada, em situação de pobreza e extrema pobreza. O condomínio Sol Nascente, localizado na Ceilândia, foi considerado pelo Instituto Brasileiro de Geografia e Estatística (IBGE) a maior favela da América Latina, ultrapassando inclusive a Rocinha e outras grandes favelas de países vizinhos, como Argentina ou Bolívia. Em Brasília fica o metro quadrado mais caro e o mais pobre da América Latina, e 18\% das famílias possuem ingressos mensais máximos de dois salários mínimos. Segundo o Programa das Nações Unidas para o Desenvolvimento (PNUD, 2013), Brasília é a quarta área metropolitana mais desigual do Brasil, e a décima sexta do mundo.

\section{A SEGREGAÇÃO SOCIOEDUCACIONAL NO DF}

\section{E A DISTRIBUIÇÃO DA INFRAESTRUTURA ESCOLAR}

O sistema público de ensino do DF é subordinado à Secretaria de Educação (SEE/DF), e constituído por 693 instituições educacionais, organizadas para atender a educação infantil, o ensino fundamental e o médio, as modalidades de ensino especial e a educação de jovens e adultos, educação profissional, estudo de língua estrangeira e artes. Essas instituições estão distribuídas de forma desconcentrada por 14 Coordenações Regionais de Ensino: Brazlândia, Ceilândia, Gama, Guará, Núcleo Bandeirante, Paranoá, Planaltina, Plano Piloto, Recanto das Emas, Samambaia, Santa Maria, São Sebastião, Sobradinho e Taguatinga ${ }^{8}$.

A segregação socioeducacional no DF está diretamente relacionada à falta de equidade na distribuição das oportunidades educacionais. A oferta de instituições de ensino foi gestada sem considerar as demandas sociais das regiões administrativas mais pobres, o que reflete a má distribuição de todos os tipos de equipamentos urbanos. Nas palavras de Peluso (2003, p. 10), "a negação do Brasil tal como era fragilizou imediatamente o projeto urbano de Brasília, pois impediu a construção de instrumentos concretos, e não racionalizantes, para tratar de uma sociedade muito complexa e que se tornava cada vez mais diferenciada".

Estudo de Schaeffer (2003) sobre os equipamentos e serviços em Brasília já apontou que, no confronto entre a área nobre do Plano Piloto e a periférica Ceilândia,

7 A Região Integrada de Desenvolvimento do Distrito Federal e Entorno (RIDE) foi criada em 1998 e é herdeira da Associação dos Municípios Adjacentes a Brasília (AMAB), criada em 1979 pelos próprios municípios, visando a cooperação intermunicipal e intergovernamental para promover estudos regionais e realizar promoção social. A RIDE incorpora 33 municípios de Goiás (29) e Minas Gerais (4). Sua instrumentalização foi regulamentada sucessivamente desde 1998. A Lei Complementar $\mathrm{n}^{\circ}$ 163/2018 definiu os municípios que atualmente a integram.

8 Segundo Paiva (2012), o termo "desconcentração" indicaria que as escolas estão organizadas regionalmente (antigamente, diretorias regionais de ensino, atualmente, coordenações), e submetidas à unidade gestora, mas essa unidade gestora não possui autonomia, e atuam como executoras das políticas emanadas da SEE/DF. 
se verifica inicialmente a existência de uma distribuição homogênea de equipamentos coletivos educacionais (considerando $\mathrm{km}$ e número de escolas). Entretanto, quando consideramos a distribuição em relação à quantidade de população em cada território, a Ceilândia concentrava, em 2002,18,80\% da população do DF e detinha $15,71 \%$ das unidades escolares instaladas no território; enquanto no Plano Piloto havia 15,88\% de unidades escolares para atender $11,18 \%$ da população escolar do DF. Schaeffer chama a atenção ainda para o fato de as frações altas e médias que habitam as áreas nobres de Brasília não serem usuárias desses equipamentos coletivos, enquanto em Ceilândia, habitada prioritariamente pelas classes trabalhadoras, esses equipamentos são essenciais.

Paiva (2012) também destaca que a distribuição das instituições educacionais pelas regionais não atende ao critério populacional, mas ao critério de classe social, porque as escolas com melhor localização possuem melhor estrutura e foram concebidas na expectativa de desenvolver integralmente a formação dos estudantes, a exemplo das escolas destinadas à formação artística/cultural e de língua estrangeira, que se encontram concentradas no Plano Piloto. Isso explicaria a escassez desses equipamentos nas regionais destacadas como mais pobres, sem Escolas Parque, Escolas de Música ou Centros de Língua Estrangeira.

Os dados mostram que todas famílias em situação crítica nesta dimensão apresentam pelo menos uma pessoa de 15 a 17 anos na família e pelo menos um estudante em defasagem escolar. É interessante notar que o grupo crítico apresenta uma renda familiar média superior ao grupo em condições menos desfavoráveis. Uma hipótese que pode explicar esse fato é que, como as famílias possuem necessariamente um jovem em faixa etária produtiva, este esteja contribuindo com a renda familiar. O fato da metodologia agrupar tais condições como pobreza, mesmo o grupo apresentando renda superior, é adequado. A renda familiar mais alta, ao preço de uma escolarização inadequada, compromete a geração futura de renda, uma vez o jovem não se qualifica. A pobreza crítica nesta dimensão é bastante abrangente, o percentual de famílias chega a 17,5\% (representando pouco mais de 20 mil famílias). [...] as RAs com piores resultados foram Planaltina, Itapoã, Santa Maria, Recanto das Emas, Samambaia e Ceilândia. (Codeplan, 2015, p. 23).

Interessante ressaltar que são as mesmas regiões administrativas nas quais se destaca a falta de frequências escolares, apesar de a frequência constituir condicionalidade do PBF. Em 2015, segundo a Codeplan, os locais onde registraram-se maior quantitativo de famílias com crianças de 7 a 14 anos fora da escola são: Planaltina, Itapoã, Santa Maria, Recanto das Emas, Samambaia e Ceilândia. Com relação à amplitude, Planaltina, Paranoá, Itapoã, SIA e Scia/Estrutural apresentam os piores resultados (Codeplan, 2015, p. 27).

A Codeplan (2015), com base no Cadastro Único do Governo Federal para Programas Sociais, ${ }^{9}$ tão importante na atualidade para a distribuição do auxílio

9 "O Cadastro Único do Governo Federal para Programas Sociais é uma base de dados nacional, com foco em famílias de baixa renda (até $1 / 2$ salário mínimo, ou até três salários mínimos de renda familiar mensal). Ele permite uma caracterização socioeconômica detalhada dessas famílias, possibilitando aos governos federal, estadual e municipal identificarem demandas específicas para o desenvolvimento de diferentes políticas públicas."(Codeplan, 2015,p. 19). 
emergencial em momentos de pandemia, elaborou um estudo sobre o impacto das pobrezas nas famílias do DF. Em julho de 2015, o Cadastro Único do DF continha em torno de 228 mil famílias, das quais 117.193 tinham dados atualizados. Considerando o DF, $14 \%$ da população está cadastrada, e especificamente com relação ao PBF, há uma cobertura relativamente alta, alcançando $77,7 \%$ dos elegíveis no DF. O percentual de famílias varia significativamente entre as regiões administrativas, desde 0,1\% no Sudoeste e no Jardim Botânico (que também registram as rendas familiares mais altas), até $53 \%$ no Varjão (que registra também uma das menores rendas familiares). São Regiões Administrativas com alto percentual de famílias cadastradas, cerca de $1 / 3$ das famílias contempladas pelo Cadastro Único do DF: Estrutural, Itapoã, Brazlândia, Fercal, Paranoá e Planaltina. A média de pessoas por família é de três pessoas, e a média de anos de estudo do responsável familiar é de sete anos (ensino fundamental incompleto). Ao analisarmos dados de 2019 na Figura 1, podemos observar poucas alterações quanto à distribuição dos alunos beneficiários do $\mathrm{PBF}$ entre as regiões administrativas.

Observa-se, na Figura 1, a relação entre a segregação socioespacial no DF e a distribuição dos alunos beneficiários do PBF entre as regiões administrativas. Enquanto as regiões mais centrais possuem baixo número de beneficiários, as regiões mais afastadas possuem grande quantidade de alunos que necessitam do benefício, com destaque para Ceilândia (representada pelo número 9), Samambaia (12) e Planaltina (6).

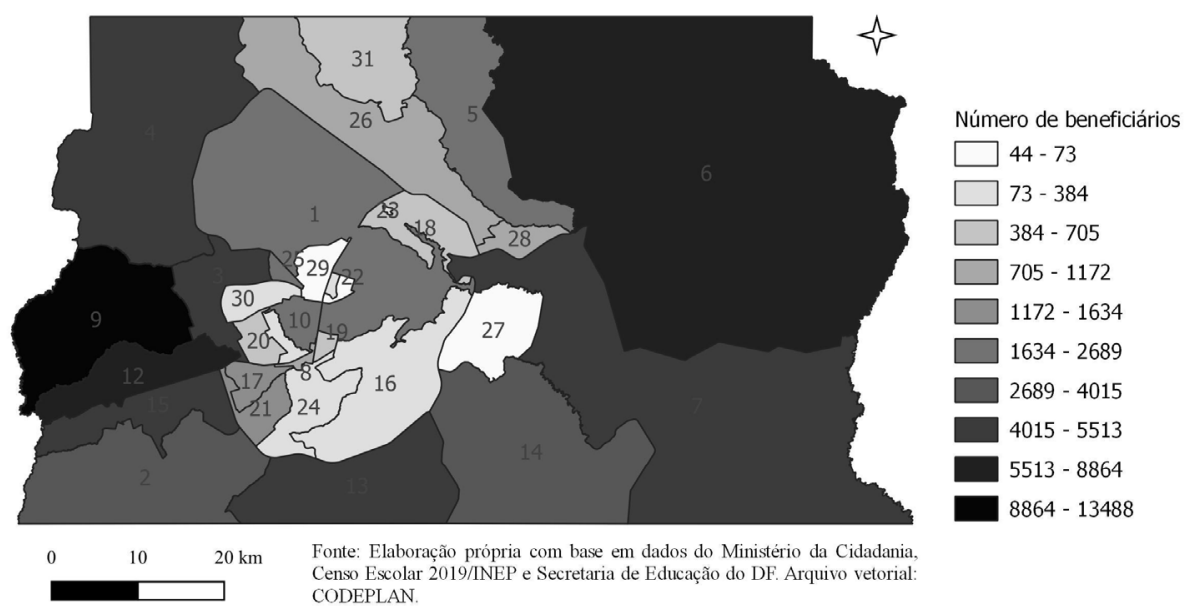

Figura 1 - Distribuição dos alunos beneficiários do Programa Bolsa Família, por região administrativa - Distrito Federal, 2019.

Codeplan: Companhia de Planejamento do Distrito Federal; DF: Distrito Federal; INEP: Instituto Nacional de Estudos e Pesquisas Educacionais Anísio Teixeira.

Códigos das regiões administrativas: 1 - Brasília, 2 - Gama, 3 - Taguatinga, 4 - Brazlândia, 5 - Sobradinho, 6 - Planaltina, 7 - Paranoá, 8 - Núcleo Bandeirante, 9 - Ceilândia, 10 - Guará, 11 - Cruzeiro, 12 - Samambaia, 13 - Santa Maria, 14 - São Sebastião, 15 - Recanto das Emas, 16 - Lago Sul, 17 - Riacho Fundo I, 18 - Lago Norte, 19 - Candangolândia, 20 - Águas Claras, 21 - Riacho Fundo II, 22 - Sudoeste/Octogonal, 23 - Varjão, 24 - Park Way, 25 - Scia, 26 - Sobradinho II, 27 Jardim Botânico, 28 - Itapoã, 29 - Setor de Indústria e Abastecimento (SIA), 30 - Vicente Pires, 31 - Fercal. 
Também há um alto percentual de alunos com idade superior à recomendada em cada nível de ensino. Segundo dados do INEP, o DF apresentou distorção idade-série de 17,3\% no ensino fundamental e de $28 \%$ no ensino médio em 2011. Essa distorção caiu no período 2006-2011, o que sugere uma diminuição progressiva na quantidade de alunos matriculados em classes não compatíveis com sua idade. O Índice de Desenvolvimento da Educação Básica (IDEB) é calculado de dois em dois anos, a partir da avaliação dos alunos nos anos iniciais e finais do ensino fundamental e no $3^{\circ}$ ano do ensino médio. O IDEB do DF, em 2011, apresentou índices superiores aos do Brasil em todas as etapas da Educação Básica (Codeplan, 2013, p. 12 $)^{10}$.

A política educacional do Distrito Federal apresentou alguns avanços nos últimos anos, principalmente no que se refere à disponibilização de estruturas adequadas nas escolas para o atendimento aos alunos. $\mathrm{O}$ aumento considerável de recursos financeiros para custeio da educação no período de 2007 a 2011 pode ter contribuído para esses avanços. O número de alunos por turma está adequado aos limites sugeridos no Projeto de Lei do Senado (PLS) 504/11. A exceção é o ensino médio, que ultrapassa em apenas 1,7 alunos a meta de 35 alunos por turma. O número de escolas com vias e sanitários acessíveis a deficientes físicos e com acesso à internet banda larga também aumentaram gradativamente. E, mesmo em casa, o recurso da internet já está disponível para crianças e adolescentes em mais de 50\% dos domicílios do Distrito Federal. (Codeplan, 2012, p. 32).

Em relação à infraestrutura física, é importante refletir sobre o que pode ser considerada uma estrutura escolar adequada ou inadequada, e qual a sua relação com a exclusão, a desigualdade social e a segregação socioeducacional. A equidade na oferta do ensino, no Brasil, está prevista no artigo 206 da Constituição Federal, segundo o qual se deve seguir, entre outros princípios, a "igualdade de condições para o acesso e permanência na escola” (Brasil, 1988). O artigo 214, ainda da Constituição Federal, provém a determinação da construção de um plano nacional de educação com diversos objetivos, entre os quais a melhoria da qualidade do ensino. Com base nesse dispositivo constitucional, foi publicada a lei n. 10.172, de 9 de janeiro de 2001: o Plano Nacional de Educação (PNE) 2001-2011. Esse plano determinou que fossem elaborados, dentro de um ano, padrões mínimos de infraestrutura para o funcionamento adequado de instituições de educação infantil, ensino fundamental, ensino médio e aquelas que atendem indígenas e alunos com deficiência, bem como

10 O MEC, por meio do INEP, implantou, em 2007, o Índice de Desenvolvimento da Educação Básica (IDEB). Esse indicador considera o desempenho médio dos alunos no Sistema Nacional de Avaliação da Educação Básica (Saeb) no $5^{\circ}$ e $9^{\circ}$ ano do ensino fundamental e $3^{\circ}$ ano do ensino médio com a taxa média de aprovação da mesma etapa de ensino, apurada pelo Censo Escolar. O IDEB tem sido adotado pelo MEC como critério para definir escolas e municípios que recebem suporte técnico e financeiro no âmbito dos programas que integram o Plano de Desenvolvimento da Educação (PDE). 
normas para a exigência de melhoria da infraestrutura de laboratórios, equipamentos e bibliotecas das instituições de educação superior (Brasil, 2001).

Como consequência das determinações do PNE 2001-2011, foram editados pelo Ministério da Educação (MEC) os seguintes documentos: Padrões Mínimos de Funcionamento da Escola de Ensino Fundamental (Brasil, 2006a), Parâmetros Básicos de Infra-Estrutura para Instituições de Educação Infantil (Brasil, 2006b), Manual para Adequação de Prédios Escolares (MEC, 2005), Manual de Orientaçôes Técnicas (Brasil, 2007). Dos Padrões Minimos de Funcionamento da Escola de Ensino Fundamental, são definidos quatro eixos de categorização e análise da infraestrutura escolar:

1) ambiente físico escolar;

2) espaço educativo;

3) mobiliário e equipamento escolar; e

4) material didático.

Ao analisarem os dados do Censo Escolar a fim de propor uma escala para análise da infraestrutura das instituições de ensino, Soares Neto et al. (2013) constataram a necessidade de classificar as escolas em quatro níveis, de acordo com a existência dos itens de infraestrutura e equipamentos: elementar, básica, adequada e avançada, considerando como adequadas aquelas que possuem, por exemplo, sala de professores, biblioteca, laboratório de informática, sanitário para a educação infantil, quadra esportiva, parque infantil, copiadora e acesso à internet - para os autores, itens representantes de infraestrutura e equipamentos mais propícios à aprendizagem. Em seu estudo, Gomes e Duarte (2017) se basearam nos eixos dos formulários de coleta do Censo Escolar para definir quatro categorias relativas à infraestrutura: recursos básicos, dependências, equipamentos e instalações didáticas. No estudo de Gomes e Regis (2012), os autores utilizaram dados da Prova Brasil e do Censo Escolar, do qual selecionaram as seguintes variáveis: sala dos professores, laboratório de informática, laboratório de ciências, quadra de esportes, biblioteca e sala de leitura.

Para analisarmos a infraestrutura das escolas do DF, retomaremos dois eixos previstos nos Padrões Minimos de Funcionamento da Escola de Ensino Fundamental (MEC, 2002): ambiente físico escolar e espaço educativo. Desses, selecionamos, em especial, aspectos relativos a saneamento básico, existência de biblioteca ou sala de leitura, laboratório de informática e quadra de esporte. Utilizamos os microdados do Censo Escolar 2018 e selecionamos as escolas públicas do DF em atividade naquele ano.

A coleta do Censo Escolar é feita por meio de diferentes formulários, relacionados às características das escolas e a informações sobre alunos e profissionais escolares ${ }^{11}$. Neste estudo, utilizamos o formulário de escola. Ao analisarmos os dados do Censo Escolar 2018 em relação ao saneamento básico das escolas que atendem

11 Até 2018, a coleta do Censo Escolar possuía quatro formulários: escola, turma, profissional escolar em sala de aula e aluno. Em 2019, foi adicionado o formulário sobre o gestor escolar. 
beneficiários do PBF, observamos que todas têm acesso a água potável, energia elétrica e coleta de esgoto, motivo pelo qual esses itens não foram considerados para a comparação entre as escolas. Quanto à coleta de lixo, duas escolas - em São Sebastião e Paranoá - não são atendidas, mas descartam o lixo por meio de queima, reciclagem ou enterrando-o. A disponibilidade de internet na escola, informada no item "Equipamentos" do formulário, mostrou que 21 instituições que atendem beneficiários do PBF não possuem acesso à internet, assim distribuídas de acordo com a região administrativa: 1 em Ceilândia, 4 na Fercal, 1 no Lago Norte, 5 no Paranoá, 5 em Planaltina, 1 em Samambaia, 2 em São Sebastião e 2 em Sobradinho.

Após a verificação preliminar desses itens, optou-se por analisar o item "Dependências existentes na escola”, que inclui: sala de diretoria, sala de professores, laboratório de informática, laboratório de ciências, sala de recursos para atendimento educacional especializado, quadra de esportes coberta, quadra de esportes descoberta, cozinha, biblioteca, sala de leitura, parque infantil, berçário, banheiro fora do prédio, banheiro dentro do prédio, banheiro adequado à educação infantil, banheiro acessível adequado ao uso dos alunos com deficiência ou mobilidade reduzida, dependências e vias adequadas a alunos com deficiência ou mobilidade reduzida, sala de secretaria, banheiro com chuveiro, refeitório, despensa, almoxarifado, auditório, pátio coberto, pátio descoberto, alojamento de aluno, alojamento de professor, área verde e lavanderia ${ }^{12}$. Considerando as especificidades das séries atendidas em cada escola e o perfil variável do público, foram selecionados para a análise final as dependências que podem ser utilizadas no trabalho pedagógico em qualquer série e que não estão ligadas primordialmente à administração da escola, quais sejam: sala de professores, laboratório de informática, quadra de esportes (coberta ou descoberta), cozinha, biblioteca ou sala de leitura, banheiro dentro do prédio, banheiro acessível a alunos com deficiência, refeitório, auditório, pátio (coberto ou descoberto) e área verde.

Com base na análise dos itens, constatou-se que a dependência menos encontrada nas escolas foi o auditório: das 574 escolas públicas analisadas, 503 não possuem esse espaço. Em seguida, vem o refeitório, ausente em 455 escolas; área verde, ausente em 279 escolas; quadra de esportes, ausente em 170 escolas; e laboratório de informática, ausente em 128 escolas. Na Tabela 2, apresentamos o percentual de existência das dependências analisadas entre as escolas selecionadas para o estudo.

Merece atenção o fato de apenas 20,73\% das escolas que atendem beneficiários do $\mathrm{PBF}$ possuírem refeitório, considerando a importância da alimentação escolar para os alunos em situação de pobreza. Apesar disso, quase todas as escolas possuem cozinha.

12 As dependências físicas declaradas podem não ser correspondentes ao compararmos anos diferentes, em virtude de atualizações nos formulários de coleta do Censo Escolar. Entre outras alterações, em 2019, as opções "banheiro fora do prédio" e "banheiro dentro do prédio" foram substituídas por "banheiro" e "banheiro exclusivo para funcionários". 
Tabela 2 - Distribuição das dependências escolares nas escolas que atendem beneficiários do Programa Bolsa Família - Distrito Federal, 2018/2019.

\begin{tabular}{l|c}
\hline Dependência & Existência nas escolas (\%) \\
\hline Sala de professores & 98,95 \\
\hline Laboratório de informática & 77,7 \\
\hline Quadra de esportes & 70,38 \\
\hline Cozinha & 99,3 \\
\hline Biblioteca ou sala de leitura & 90,41 \\
\hline Banheiro dentro do prédio & 99,65 \\
\hline Banheiro acessível & 82,92 \\
\hline Refeitório & 20,73 \\
\hline Auditório & 12,36 \\
\hline Pátio & 90,94 \\
\hline Área verde & 51,39 \\
\hline
\end{tabular}

Fonte: Elaboração própria, com base em dados do Censo Escolar 2018 do Instituto Nacional de Estudos e Pesquisas Educacionais Anísio Teixeira, do Ministério da Cidadania e da Secretaria de Educação do Distrito Federal.

Ao final, as escolas foram divididas em dois grupos: as que possuem menos da metade dos itens de infraestrutura analisados, e as que possuem mais da metade. A partir disso, foi mapeada a distribuição por região administrativa das escolas que possuem mais de $50 \%$ dos itens, o que pode ser verificado na Figura 2.

Pela Figura 2, é possível observar uma situação inversa à distribuição dos alunos beneficiários do PBF: Planaltina (6), que possui grande número de beneficiários, possui menor número de escolas com melhor infraestrutura, enquanto Park Way (24), por exemplo, possui mais escolas com boa infraestrutura e menor número de beneficiários. Para algumas regiões administrativas de menor renda e maior número de beneficiários, entretanto, identifica-se maior número de escolas com boa infraestrutura; é o caso de Itapoã. Isso se deve, em parte, ao fato de essa região possuir escolas com menos de 20 anos, já construídas segundo critérios padronizados de qualidade.

\section{CONSIDERAÇÕES FINAIS}

A oferta de instituições de ensino no DF foi gestada sem considerar as demandas sociais das regiões administrativas mais pobres, o que reflete a má distribuição de todos os tipos de equipamentos urbanos. Enquanto as regiões mais centrais possuem baixo número de beneficiários, as regiões mais afastadas possuem grande quantidade de alunos que necessitam do benefício, com destaque para Ceilândia, Samambaia e Planaltina. Também há um alto percentual de alunos com idade superior à recomendada em cada nível de ensino. $\mathrm{O} D F$ apresentou distorção idade-série de 17,3\% no ensino fundamental e de $28 \%$ no ensino médio em 2011. 


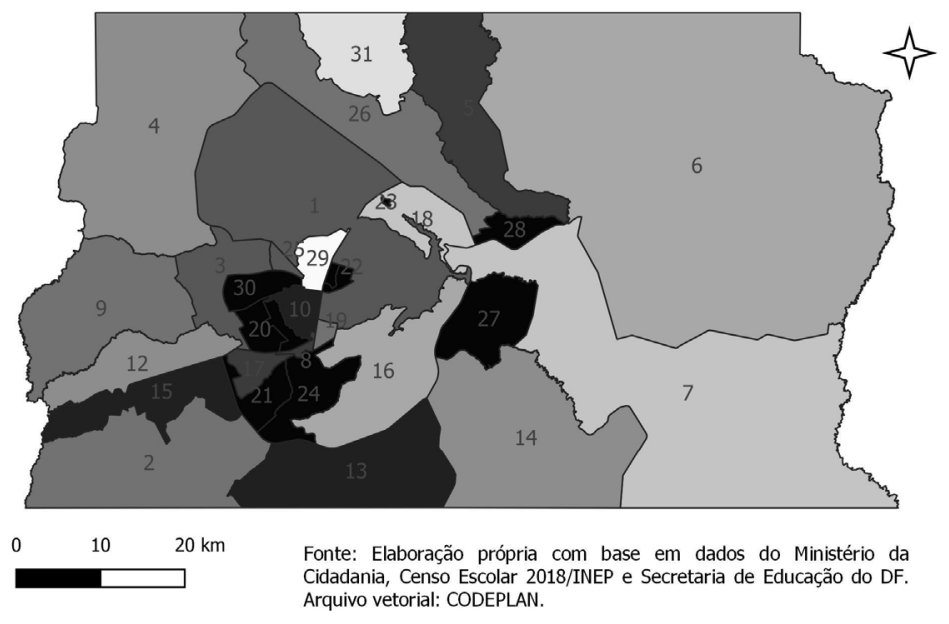

Infra por RA

$\square 0-0$

$\square 0-20$

$\square 20-50$

$\square 50-67,7$

$67,7-73,1$

$73,1-77,5$

$77,5-82,7$

$82,7-87,5$

$87,5-95,8$

$95,8-100$

Figura 2 - Porcentagem de escolas que atendem beneficiários do Programa Bolsa Família com mais de 50\% dos itens de infraestrutura analisados, por região administrativa - Distrito Federal, 2018/2019.

Codeplan: Companhia de Planejamento do Distrito Federal (Codeplan); DF: Distrito Federal; INEP: Instituto Nacional de Estudos e Pesquisas Educacionais Anísio Teixeira; RA: Região Administrativa.

Códigos das regiões administrativas: 1 - Brasília, 2 - Gama, 3 - Taguatinga, 4 - Brazlândia, 5 - Sobradinho, 6 - Planaltina, 7 - Paranoá, 8 - Núcleo Bandeirante, 9 - Ceilândia, 10 - Guará, 11 - Cruzeiro, 12 - Samambaia, 13 - Santa Maria, 14 - São Sebastião, 15 - Recanto das Emas, 16 - Lago Sul, 17 - Riacho Fundo I, 18 - Lago Norte, 19 - Candangolândia, 20 - Águas Claras, 21 - Riacho Fundo II, 22 - Sudoeste/Octogonal, 23 - Varjão, 24 - Park Way, 25 - Scia, 26 - Sobradinho II, 27 Jardim Botânico, 28 - Itapoã, 29 - Setor de Indústria e Abastecimento (SIA), 30 - Vicente Pires, 31 - Fercal.

Ao analisarmos os dados do Censo Escolar 2018 em relação ao saneamento básico das escolas que atendem beneficiários do $\mathrm{PBF}$, observou-se que, quanto à coleta de lixo, duas escolas — em São Sebastião e Paranoá — não são atendidas, mas descartam o lixo por meio de queima, reciclagem ou enterrando-o; quanto à disponibilidade de internet na escola, 21 escolas que atendem beneficiários do $\mathrm{PBF}$ não possuem acesso à internet; e que a dependência menos encontrada nas escolas foi o auditório: das 574 escolas públicas analisadas, 503 não possuem esse espaço. Em seguida, vem o refeitório, ausente em 455 escolas; área verde, ausente em 279 escolas; quadra de esportes, ausente em 170 escolas; e laboratório de informática, ausente em 128 escolas. Merece atenção o fato de apenas 20,73\% das escolas que atendem beneficiários do $\mathrm{PBF}$ possuírem refeitório, considerando a importância da alimentação escolar. Apesar disso, quase todas as escolas possuem cozinha. Finalmente, foi possível observar uma situação inversa à distribuição dos alunos beneficiários do PBF: quanto maior o número de beneficiários, menor e pior a infraestrutura escolar.

Apesar dos limites da pesquisa, é possível identificar aspectos da segregação educacional entre a população do DF, que colocam, de um lado, elevada renda per capita e melhor infraestrutura escolar, e, de outro lado, muitas famílias que necessitam de um benefício para garantir a subsistência frequentando poucas escolas e em condições precárias. A análise desenvolvida neste artigo corrobora os resultados da análise documental sobre a escola pública do DF (ver Pinelli; Yannoulas; 2019). As questões 
relativas à pobreza e desigualdade social são tratadas de maneira precária ou superficial nos planos e programas educacionais no DF. A segregação socioeducacional no DF está diretamente relacionada à falta de equidade na distribuição das oportunidades educacionais e invisibilizada nos documentos que orientam a política distrital.

\section{REFERÊNCIAS}

ALAVARSE, O.M. A organização do ensino fundamental em ciclos: algumas questões. Revista Brasileira de Educação, Rio de Janeiro, v. 14, n. 40, p. 35-50, jan./abr. 2009. Disponível em: https://doi.org/10.1590/S1413-24782009000100004. Acesso em: 18 ago. 2021.

ALVES, T.; PASSADOR, C. S. Educação pública no Brasil: condições de oferta, nível socioeconômico dos alunos e avaliação. São Paulo: Annablume, 2011.

BEN-AYED, C. Territorialização da ação educativa. In: VAN ZANTEN, A. (coord.). Dicionário de educação. Petrópolis: Vozes, 2011. p. 763-766.

BOTTINELLI, L. Educación y desigualdad. Un repaso por algunos aportes de la sociología de la educación em la Argentina. Revista Sociedad, Buenos Aires, n. 37, p. 95-111, outono 2017. Disponível em: https://publicaciones.sociales.uba.ar/index.php/ revistasociedad/article/view/2974. Acesso em: 9 abr. 2020.

BRASIL. Constituição da República Federativa do Brasil (1988). Brasília: Casa Civil, 1988. Disponível em: http://www.planalto.gov.br/ccivil_03/constituicao/ ConstituicaoCompilado.htm. Acesso em: 9 set. 2021.

BRASIL. Lei n. 10.172, de 9 de janeiro de 2001. Aprova o Plano Nacional de Educação e dá outras providências. Diário Oficial da União, Poder Executivo, Brasília, DF, 10 jan. 2001. Seção 1, p. 1. Disponível em: http://www2.camara.leg.br/legin/fed/lei/2001/lei10172-9-janeiro-2001-359024-publicacaooriginal-1-pl.html. Acesso em: 9 set. 2021.

BRASIL. Ministério da Educação. Manual para Adequação de Prédios Escolares. Elaboração: Carlos Alberto Araújo Guimarães, Cláudia Maria Videres Trajano, Erinaldo Vitório, Rodolfo Oliveira Costa, Willamy Mamede da Silva Dias. 5. ed. Brasília: Fundo de Fortalecimento da Escola; Divisão de Protocolo; Fundo Nacional de Desenvolvimento da Educação; Ministério da Educação, 2005.

BRASIL. Ministério da Educação. Padrões mínimos de funcionamento da escola do ensino fundamental: manual de implantação. Coordenação: Karla Motta Kiffer de Moraes. 2. imp. Brasília: Fundo de Fortalecimento da Escola; Divisão de Protocolo; Fundo Nacional de Desenvolvimento da Educação; Ministério da Educação, 2006a.

BRASIL. Ministério da Educação. Secretaria de Educação Básica. Parâmetros básicos de infra-estrutura para instituições de educação infantil. Brasília: Ministério da Educação; Sistema Educacional Brasileiro, 2006b.

BRASIL. Fundo Nacional de Desenvolvimento da Educação. Resolução CD/FNDE n. 006, de 24 de abril de 2007. Estabelece as orientações e diretrizes para execução e assistência financeira suplementar ao Programa Nacional de Reestruturação e Aquisição de Equipamentos para a Rede Escolar Pública de Educação Infantil - PROINFÂNCIA. Diário Oficial da União, Brasília, 24 abr. 2007. 
BRASLAVSKY, C. La discriminación educativa en Argentina. Buenos Aires: Facultad Latinoamericana de Ciencias Sociales; Grupo Editor de América Latina, 1985.

CAMPOS, N. L. O. A segregação planejada. In: PAVIANI, A. (org.). A conquista da cidade: movimentos populares em Brasília. Brasília: Editora Universidade de Brasilia, 1991. CODEPLAN - COMPANHIA DE PLANEJAMENTO DO DISTRITO FEDERAL. Avaliação da Educação Básica no DF: uma visão do IDEB. Brasília: Codeplan, 2013. Disponível em: http://www.codeplan.df.gov.br/wp-content/ uploads/2018/02/Educa\%C3\%A7\%C3\%A3o-B\%C3\%A1sica-no-Distrito-FederalUma-Vis\%C3\%A3o-do-Ideb.pdf. Acesso em: 6 abr. 2020.

CODEPLAN - COMPANHIA DE PLANEJAMENTO DO DISTRITO FEDERAL (Codeplan). Catálogo de Mapas da Codeplan. Disponível em: http:// catalogo.codeplan.df.gov.br/. Acesso em: 1 maio 2020.

CODEPLAN - COMPANHIA DE PLANEJAMENTO DO DISTRITO FEDERAL (Codeplan). Desenvolvimento social, pobreza, educação e saúde. Brasília: Codeplan, 2012. Disponível em: http://www.codeplan.df.gov.br/wp-content/ uploads/2018/02/Desenvolvimento-Social-do-DF-Pobreza-Educa\%C3\%A7\%C3\%A3oe-Sa\%C3\%BAde-diagn\%C3\%B3stico.pdf. Acesso em: 09 abr. 2020.

CODEPLAN - COMPANHIA DE PLANEJAMENTO DO DISTRITO FEDERAL (Codeplan). Índice multidimensional de pobreza (IMP): as dimensões da pobreza no Distrito Federal e suas Políticas de Enfrentamento. Texto para Discussão, Brasília, n. 6, set. 2015. Disponível em: http://www.codeplan.df.gov.br/wp-content/ uploads/2018/02/TD_6_As_Dimens\%C3\%B5es_da_Pobreza_no_DF_e_suas_ Pol\%C3\%ADticas_de_Enfrentamento.pdf. Acesso em: 09 abr. 2020.

CODEPLAN - COMPANHIA DE PLANEJAMENTO DO DISTRITO FEDERAL (Codeplan). Pesquisa Distrital por Amostra de Domicílios 2018. Disponível em: http://www.codeplan.df.gov.br/pdad-2018/. Acesso em: 31 mar. 2020 .

CODEPLAN - COMPANHIA DE PLANEJAMENTO DO DISTRITO FEDERAL (Codeplan). Síntese Estatística DF 2018. Disponível em: http://infodf. codeplan.df.gov.br/?page_id=2254. Acesso em: 30 mar. 2020.

D'AGOSTINI, A. et al. Desigualdades sociais e escolares: infância e juventude nas voltas que o mundo dá. In: GARCIA, A. V. et al. (org.). Reflexões sobre a pobreza: educação e assistência. v. 2. Florianópolis: NUP/CED/UFSC, 2017. p. 101-151.

DUARTE, N. O impacto da pobreza no IDEB: um estudo multinível. Revista Brasileira de Estudos Pedagógicos, Brasília, v. 94, n. 237, p. 343-363, maio/ago. 2013. Disponível em: https://doi.org/10.24109/2176-6681.rbep.94i237.369. Acesso em: 9 abr. 2020.

FREITAS, L. C. A internalização da exclusão. Educação e Sociedade, Campinas, v. 23, n. 80, p. 299-325, set. 2002. Disponível em: https://doi.org/10.1590/s010173302002008000015. Acesso em: 09 abr. 2020.

GASPARINI, L.; JAUME, D.; SERIO, M.; VÁZQUEZ, E. La segregación entre escuelas públicas y privadas en Argentina. Reconstruyendo la evidencia. Desarrollo 
Económico, Buenos Aires, v. 51, n. 202/203, p. 189-219, jul./dez.2011. Disponível em: http://www.jstor.org/stable/23612381. Acesso em: 10 fev. 2021.

GENTILI, P. (org.). Pedagogia da exclusão: crítica ao neoliberalismo em educação. 11. ed. Petrópolis: Vozes, 2002.

GOMES, A.; REGIS, A. Desempenho e infraestrutura: mapeamento das escolas públicas da região metropolitana do Rio de Janeiro. In: CONGRESSO IBEROAMERICANO DE POLÍTICA E ADMINISTRAÇÃO DA EDUCAÇÃO, 3., 2012, Saragoça. Anais [...]. Saragoça: Conservatório Superior de Música de Aragón, 2012.

GOMES, C. A.T.; DUARTE, M. R. T. Os últimos serão os mais pobres? Evolução da desigualdade de infraestrutura escolar no Brasil (2007-2013). In: GARCIA, A. V. et al. (org.). Formação e pesquisa no âmbito da iniciativa educação, pobreza e desigualdade social. v. 3. Florianópolis: NUP/CED/UFSC, 2017. p. 243-293.

GUERRA, A.; POCHMANN, M.; SILVA, R. A. (org.). Atlas da Exclusão Social no Brasil: dez anos depois. v. 1. São Paulo: Cortez Editora, 2014.

GUIMARAES-IOSIF, R. Educação, pobreza e desigualdade no Brasil. Brasília: Liber Livros, 2009.

IBGE - INSTITUTO BRASILEIRO DE GEOGRAFIA E ESTATÍSTICA. Estatísticas: Brasília (DF). Disponível em: https://www.ibge.gov.br/cidades-eestados/df/brasilia.html?. Acesso em: 05 abr. 2020.

INEP - INSTITUTO NACIONAL DE ESTUDOS E PESQUISAS EDUCACIONAIS ANÍSIO TEIXEIRA. Censo Escolar 2019. Disponível em: http://portal.INEP.gov.br/censo-escolar. Acesso em: 07 abr. 2020.

INEP - INSTITUTO NACIONAL DE ESTUDOS E PESQUISAS EDUCACIONAIS ANÍSIO TEIXEIRA Índice de Desenvolvimento da Educação Básica - IDEB. Disponível em: http://portal.INEP.gov.br/ideb. Acesso em: 07 abr. 2020.

LOPES, M. A.; COSTA, V. G. Segregação e periferização em cidades planejadas - o caso de Brasília. In: ENCONTRO DE GEÓGRAFOS DA AMÉRICA LATINA, 10., 2005, São Paulo. Anais [...]. São Paulo: Universidade de São Paulo, 2005. Disponível em: http://observatoriogeograficoamericalatina.org.mx/egal10/ Geografiasocioeconomica/Geografiadelapoblacion/33.pdf. Acesso em: 30 mar. 2020. MALOUTAS, T. Efeitos de vizinhança e desempenhos escolares. In: VAN ZANTEN, Agnès (coord.). Dicionário de educação. Petrópolis: Vozes, 2011. p. 288-291.

MINISTÉRIO DA CIDADANIA. Bolsa Família: dados. Disponível em: http:// mds.gov.br/assuntos/bolsa-familia/dados. Acesso em: 07 abr. 2020.

OBERTI, M. Segregação escolar e urbana. In: VAN ZANTEN, Agnès (coord.). Dicionário de educação. Petrópolis: Vozes, 2011. p. 727-730.

OLIVEIRA, D. A. Educação básica: gestão do trabalho e da pobreza. Petrópolis: Vozes, 2000. 
OPEN SOURCE GEOSPATIAL FOUNDATION (OSGeo). QGIS. Disponível em: https://qgis.org/pt_BR/site/about/index.html. Acesso em: 30 mar. 2020.

PAIVA, O. A. F. Contradições dos programas de transferência de renda no campo da educação. Brasília: Liber Livros, 2012.

PELUSO, M. L. Brasília: do mito ao Plano, da cidade sonhada à cidade administrativa. Espaço \& Geografia, v. 6, n. 2, p. 1-29, 2003. Disponível em: http:// www.1sie.unb.br/espacoegeografia/index.php/espacoegeografia/article/view/26. Acesso em: 9 abr. 2020.

PEREGRINO, M. Trajetórias desiguais: um estudo sobre os processos de escolarização pública de jovens pobres. Rio de Janeiro: Garamond, 2010.

PINELLI, L. V.; YANNOULAS, S. C. Política Educacional y pobreza en Brasilia: un análisis crítico del Plan Distrital de Educación. Cuestión Urbana, ano 3, n. 6, p. 33-46, dez. 2019. Disponível em: https://publicaciones.sociales.uba.ar/index.php/ cuestionurbana/article/view/5321/4379. Acesso em: 30 mar. 2020.

PRETECEILLE, E. Segregação Urbana. In: IVO, A. B. L. (coord.). Dicionário temático desenvolvimento e questão social. São Paulo: Annablume, 2013. p. 442-449.

PROGRAMA DAS NAÇÕES UNIDAS PARA O DESENVOLVIMENTO (PNUD). Atlas do Desenvolvimento Humano - 2012 a 2017. Publicado em 2013. Disponível em: https://onedrive.live.com/?authkey=\%21AKWQ6wc466CJtME\& cid=124653557C0404EC\&id=124653557C0404EC\%2123007\&parId=12465355 7C0404EC\%2122848\&o=OneUp. Acesso em: 09 set. 2021.

PORTO-GONÇALVES, C. W. De saberes e de territórios: diversidade e emancipação a partir da experiência latino-americana. GEOgraphia, n. 16, p. 37-51, 2006. Disponível em: https://doi.org/10.22409/geographia2006.816.a13521. Acesso em: 19 ago. 2021.

RIBEIRO, V. M.; VÓVIO, C. L. Desigualdade escolar e vulnerabilidade social no território. Educar em Revista, Curitiba, n. 2, p. 71-87, 2017. Disponível em: https:// doi.org/10.1590/0104-4060.51372. Acesso em: 09 abr. 2020.

SARAIVA, A. M. A. O trabalho docente em territórios de alta vulnerabilidade social: condições de trabalho, permanência e desempenho. 2015. Tese (Doutorado em Educação) - Universidade Federal de Minas Gerais, Belo Horizonte, 2015. Disponível em: https://repositorio.ufmg.br/bitstream/1843/BUOS-9VERKL/1/ tese_fim.pdf. Acesso em: 12 abr. 2020.

SCHAEFFER, M. F. C. Segregação socioespacial no Distrito Federal. Katálysis, Florianópolis, v. 6, n. 2, p. 237-245, dez. 2003. Disponível em: https://periodicos. ufsc.br/index.php/katalysis/article/view/7901/7309. Acesso em: 30 mar. 2020.

SCHNEIDER, G. et al. Baixa frequência nas escolas: uma análise dos estudantes vinculados ao Programa Bolsa Família. In: GARCIA, Adir Valdemar et al. (org.). Reflexões sobre a pobreza: concepções, enfrentamentos e contradições. Florianópolis: NUP/CED/UFSC, 2017. v. 1, p. 253-290. 
SEE/DF - SECRETARIA DE ESTADO DE EDUCAÇÃO DO DISTRITO FEDERAL. Censo Escolar DF 2019. Disponível em: http://www.se.df.gov.br/ censo-escolar-2019/. Acesso em: 7 abr. 2020.

SILVA, A. P. F. Reprovados, indisciplinados, fracassados: as microrrelações de insucesso escolar na perspectiva do "aluno problema". 2009. Tese (Doutorado em Educação) - Pontifícia Universidade Católica de São Paulo, São Paulo, 2009. Disponível em: https://tede2.pucsp.br/handle/handle/10759. Acesso em: 30 mar. 2020.

SILVEIRA, A. et al. O direito à educação dos alunos em situação de pobreza: uma problematização das condições de qualidade com base no perfil dos professores. Revista Em Aberto - INEP, v. 30, n. 99, p. 79-97, 2017. Disponível em: https:// doi.org/10.24109/2176-6673.emaberto.30i99.3300. Acesso em: 9 abr. 2020.

SOARES NETO, J. J.; JESUS, G. R. de; KARINO, C. A.; ANDRADE, D. F. Uma escala para medir a infraestrutura escolar. Estudos em Avaliação Educacional, v. 24, n. 54, p. 78-99, 2013. Disponível em: https://doi.org/10.18222/eae245420131903. Acesso em: 19 ago. 2021.

SPOSATI, A. Exclusão e fracasso escolar - o que pensam outros profissionais? Em Aberto, Brasília, v. 17, n. 71, p. 21-32, jan. 2000. Disponível em: http://portal.INEP.gov. $\mathrm{br} /$ documents/186968/485895/Programas \pm de \pm corre\%C3\%A7\%C3\%A3o \pm de \pm fluxo \pm e scolar/efee2579-aca5-4750-b1c4-097dfc4d5610?version=1.3. Acesso em: 12 abr. 2020. SPOSATI, A. Tendências latino-americanas da política social pública no século 21. Katálysis, Florianópolis, v. 14, n. 1, p. 104-115, 2011. Disponível em: https:// doi.org/10.1590/s1414-49802011000100012. Acesso em: 9 abr. 2020.

STOCO, S.; ALMEIDA, L. C. Escolas municipais de Campinas e vulnerabilidade sociodemográfica: primeiras aproximações. Revista Brasileira de Educação, Rio de Janeiro, v. 16, n. 48, p. 663-814, set./dez. 2011. Disponível em: https://doi. org/10.1590/s1413-24782011000300008. Acesso em: 09 abr. 2020.

TIRAMONTI, G. La educación argentina en el contexto de las transformaciones de los años 90. Pro-Posições, Campinas, v. 16, n. 3, p. 53-74, set./dez. 2005. Disponível em: https://periodicos.sbu.unicamp.br/ojs/index.php/proposic/article/ view/8643677. Acesso em: 10 fev. 2021.

VAN ZANTEN, A. (coord.). Dicionário de educação. Petrópolis: Vozes, 2011.

VINHAES, R. Prefácio. In: PAIVA, O. A. F. de. Contradições dos programas de transferência de renda no campo da educação. Brasília: Liber Livros, 2012.p. 27-33. WOLFFENBÜTTEL, A. O que é? Índice de Gini. Desafios do desenvolvimento - Instituto de Pesquisa Econômica Aplicada, ano 1, ed. 4, nov. 2004. Disponível em: https://www.ipea.gov.br/desafios/index.php?option=com content\&id=2048: catid=28. Acesso em: 19 ago. 2021.

YANNOULAS, S. C. Literatura recente sobre uma antiga problemática. In: YANNOULAS, S. C. (coord.). Política educacional e pobreza: múltiplas abordagens para uma relação multideterminada. Brasília: Liber Livros, 2013. p. 25-65. Disponível em: http://www.tedis.unb.br/images/pdf/Obeduc RelatorioFinalAtividades2013_Anexo12_Livro.pdf. Acesso em: 30 mar. 2020. 


\section{SOBRE AS AUTORAS}

Elaine de Almeida Cabral é doutoranda em Política Social pela Universidade de Brasília (UnB).

E-mail: elaine.cabral@inep.gov.br

Silvia Cristina Yannoulas é doutora em Sociologia pela Universidade de Brasília (UnB). Professora da Universidade de Brasília (UnB). E-mail: silviayannoulas@unb.br

Conflitos de interesse: As autoras declaram que não possuem nenhum interesse comercial ou associativo que represente conflito de interesses em relação ao manuscrito.

Financiamento: Não houve financiamento.

Contribuições dos autores: Investigação, Escrita - Primeira Redação: Cabral, E. Conceituação, Escrita - Revisão e Edição, Supervisão: Yannoulas, S.

Recebido em 7 de julho de 2020 Aprovado em 22 de fevereiro de 2021 